\title{
SISTEM DATA WAREHOUSE DAN DATA MINING SEBAGAI PENGUKUR KINERJA ENTERPRISE
}

\author{
Henderi ${ }^{1}$ \\ Untung Rahardja ${ }^{2}$ \\ Muhammad Yusup ${ }^{3}$ \\ e-mail : henderi@pribadiraharja.com,untung.rahardja@faculty.raharja.ac.id, \\ muhamad.yusup@faculty.raharja.ac.id,
}

Diterima :29 November 2010/Disetujui : 21 Desember 2010

\begin{abstract}
Information systems in organizations are mostly used to support of enterprise business process activities. The system is generally not able to provide strategic information and assist management in evaluating the performance of the enterprise. This happens because the most information systems built using the concept of database OLTP (online transaction processing) and to be ad hoc. This problem also occurred in the information system in most universities in the city of Tangerang which as research samples. The alternative solution is to build information systems that apply the concepts and methods of data warehouse and data mining that can be as a tool to measuring enterprise performance. The system development methodology in this solution is using developmnet system life cycle (SDLC). Thes SDLC method consists of stages: system studies, design analysis, system development, and implementation. Through this approach created an information system with the concept of data warehouse and data mining that can generate strategic information, as needed, and as tools implement enterprise performance measurement. The end result is a system of research data warehouse and data mining as a tool of enterprise performance measurement in higher education Raharja as a prototype implementation.
\end{abstract}

Keywords: business process, OLTP, data warehousing, data mining, enterprise performance measurement

1. Dosen Jurusan Teknik Informatika, STMIK Raharja

J1. jend Sudirman No. 40 Modern Cikokol-Tangerang Telp. 5529692

2. Dosen Jurusan Sistem Informasi, STMIK Raharja

J1. jend Sudirman No. 40 Modern Cikokol-Tangerang Telp. 5529692

3. Dosen Jurusan Teknik Informasi, AMIK Raharja Informatika

Jl. jend Sudirman No. 40 Modern Cikokol-Tangerang Telp. 5529692 


\section{ABSTRAKSI}

Sistem informasi pada organisasi sebagian besar digunakan untuk membantu pelaksanaan business process enterprise. Sistem tersebut pada umumnya belum dapat menyediakan informasi strategis dan membantu manajemen dalam melakukan evaluasi kinerja enterprise. Hal ini terjadi karena sistem informasi sebagian besar dibangun menggunakan konsep database OLTP (online transaction processing) dan bersifat ad hoc. Permasalahan ini terjadi pula pada sistem informasi di sebagian besar Perguruan Tinggi di Kota Tangerang sebagai sampel penelitian. Alternatif pemecahan masalah tersebut adalah membangun sistem informasi yang menerapkan konsep dan cara kerja data warehouse dan data mining yang dapat dijasikan sebagai tools pengukur kinerja enterprise. Metodologi pengembangan sistemnya menggunakan metode system developmnet life cycle (SDLC). Metode SDLC terdiri dari tahapan: system study, analysis design, system development, dan implementation. Melalui pendekatan ini diciptakan sebuah sistem informasi dengan konsep data warehouse dan data mining yang dapat menghasilkan informasi yang bersifat strategis, sesuai kebutuhan, dan sebagai tools melaksanakan pengukuran kinerja enterprise. Hasil akhir penelitian adalah sebuah sistem data warehouse dan data mining sebagai tools pengukur kinerja enterprise pada Perguruan Tinggi Raharja sebagai prototipe penerapannya.

Kata kunci : business process, OLTP, data warehouse, data mining, pengukur kinerja enterprise

\section{PENDAHULUAN}

Kegiatan organisasi saat ini dan akan datang senantiasa didukung oleh teknologi informasi dan mengarah kepada otomatisasi. Dengan dukungan teknologi informasi, organisasi (enterprise) dapat menghasilkan produk dan jasa yang berkualitas tinggi. Tidak hanya itu, data dan informasi tentang produk dan jasa enterprise menjadi sangat strategis, bersifat digital, dan terhubung satu sama lain melalui suatu jejaring kerja. Karenanya bisnis enterprise menjadi bersifat global dan sangat kompetitif. Namun, organisasi dituntut dapat memanfaatkan teknologi informasi untuk kepentingan yang lebih strategis, tidak hanya digunakan untuk mendukung kegiatan proses business enterprise.

Perluasan pemanfaatan teknologi informasi tersebut dapat dilakukan dengan melakukan terobosan dalam membuat sebuah sistem informasi atau enterprise system sebagai tools pengukur kinerja. Sistem tersebut dapat membantu manajemen dalam melakukan pengukuran kinerja enterprise. Tools ini mendukung manajemen dalam melaksanakan evaluasi dan pengukuran kinerja pencapaian target, tujuan, misi dan visi enterprise.

Sementara itu, hasil penelitian terhadap sepuluh perguruan tinggi di Kota Tangerang diketahui bahwa hanya terdapat satu sistem informasi yang dapat 
digunakan sebagai tools dalam mendukung pengambilan keputusan oleh pemimpin. Sistem tersebut dibangun menggunakan konsep data warehouse dengan skema prosesor [1]. Namun sistem tersebut belum dapat digunakan sebagai tools untuk melakukan evaluasi kinerja enterprise. Karena itu, penelitian ini hendak memecahkan permasalahan: bagaimana membuat sistem informasi yang menerapkan konsep data warehouse dan data mining sebagai tools pengukur kinerja enterprise. Dalam pembahasannya, pengembangan dan implementasi sistem dilakukan di Perguruan Tinggi Raharja bagian Penerimaan Mahasiswa Baru sebagai prototipe.

\section{Metodologi}

Sistem data warehouse dan data mining sebagai tools pengukur kinerja enterprise dalam penelitian ini dibuat dengan menggunakan metodologi system development life cycle (SDLC). Dalam pelaksanaannya, metodologi ini dilakukan dengan mempertahankan kegiatan-kegiatan sebagai berikut [2]:

a. Pengusulan feasibility study, yaitu uraian tentang proyek secara umum dan alasan pembangunan sistem yang baru.

b. Detail system secara rinci, yaitu uraian secara rinci tentang proyek tersebut, termasuk kebutuhan akan equipment, operation description, program specification, programming, systems testing, dan system documentation.

c. Implementation system, yaitu uraian tentang bagaimana sistem tersebut akan diimplementasikan.

d. Pasca implementation, yaitu masa sesudah sistem berproduksi secara teratur.

Karena data yang diolah pada sistem yang dibuat berjumlah besar, sementara teknik analisis data tradisional tidak mampu menemukan informasi penting pada data yang berjumlah besar maka pembuatan sistem juga menggunakan data mining. Metode data mining yang digunakan adalah klasifikasi data yaitu proses untuk mencari suatu himpunan model yang dapat mendiskripsikan dan membedakan kelas untuk memprediksi kelas dari suatu objek yang kelasnya belum diketahui [3].

\section{Hasil dan Pembahasan}

\subsection{Desain Database}

Design database dibuat setelah melakukan analisa terhadap data yang ada pada penerimaan mahasiswa baru sebagai objek pembuatan prototype program sistem data warehouse dan data mining sebagai tools pengukur kinerja. Desain dibuat sejalan dengan pendapat Eka Miranda, et. Al [4] bahwa data warehouse didesain dengan tujuan untuk dapat menggambarkan data yang berasal dari transaksi 
suatu sistem dan menyediakan dukungan analisis bagi pengambilan keputusan untuk penggunanya. Desain database dimulai dengan pembuatan entity relationhsip diagram, dan mentranspormasikannya kedalam bentuk logical record structure (LRS).

Matrik hubungan antara tabel dengan proses yang ada dalam sistem yang akan di-design digambarkan pada tabel 1.

Tabe1 1. Matrik hubungan antara tabel dengan proses

\begin{tabular}{|c|l|c|c|c|c|}
\hline No. & \multicolumn{1}{|c|}{ Tabel/Proses } & DM & GRD & RFG & LAP \\
\hline 1. & Presenter & & & & \\
\hline 2. & Presentasi & $\mathrm{x}$ & & & $\mathrm{x}$ \\
\hline 3. & Calon Mahasiswa & $\mathrm{x}$ & & $\mathrm{x}$ & $\mathrm{x}$ \\
\hline 4. & Asal Se kolah/PT & $\mathrm{x}$ & & $\mathrm{x}$ & $\mathrm{x}$ \\
\hline 5. & Pekerjaan & & & $\mathrm{x}$ & $\mathrm{X}$ \\
\hline 6. & Program Studi & $\mathrm{x}$ & & & $\mathrm{x}$ \\
\hline 7. & Biaya & $\mathrm{x}$ & & $\mathrm{x}$ & $\mathrm{x}$ \\
\hline 8. & Daftar & & & $\mathrm{x}$ & $\mathrm{x}$ \\
\hline 9. & Registrasi & $\mathrm{x}$ & & $\mathrm{x}$ & $\mathrm{x}$ \\
\hline
\end{tabular}

Keterangan; $\mathrm{DB}=$ Data Master; $\mathrm{GRD}=$ Grade; $\mathrm{REG}=$ Registrasi; $\mathrm{LAP}=$ Laporan

\subsection{Logical Record Structure (LRS)}

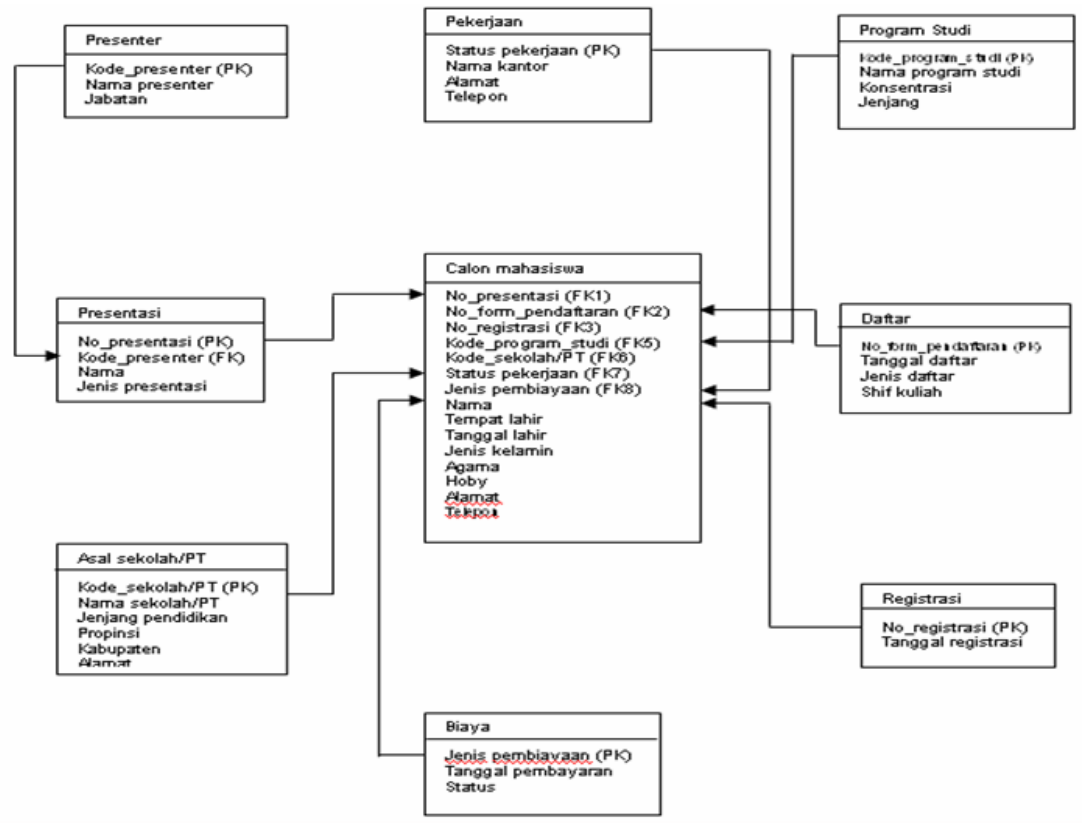

Gambar 1. Logical Record Structure (LRS) 


\subsection{Implementasi Sistem}

Sistem data warehouse dan data mining sebagai tools pengukur kinerja enterprise yang dihasilkan ditelah diuji coba pada bagian penerimaan mahasiswa baru di Perguruan Tinggi Raharja. Hasil implementasi tersebut dijelaskan sebagai berikut.

\subsubsection{Hasil Pengukuran Kinerja oleh Sistem}

Sebagian besar sistem informasi dibangun untuk mendukung pengolahan data transaksional dan operasional harian enterprise [5]. Tidak demikian dengan sistem data warehouse dan data mining sebagai tools pengukur kinerja enterprise pada penelitian ini. Sistem dibangun untuk digunakan oleh eksekutif karena dapat menghasilkan informasi yang bersifat strategis dan sesuai dengan kebutuhan eksekutif. Hasil pengukuran yang dilakukan sistem terbukti memperkuat pendapat Henry Antonius, et. al [6] tentang aplikasi data warehouse yang dibuat dan terapkannya pada rumah sakit. Pengukuran kinerja enterprise pada sistem diukur berdasarkan capaian key performance indicator (KPI) yang telah ditetapkan sebelumnya. Pada implementasi sistem, KPI yang diukur terdiri dari: (i) presentsi luas (PL), (ii) presentasi murni (PM), (iii) mahasiswa daftar, (iv) mahasiswa registrasi, (iv) registrasi perjurusan dan per-konsentrasi, dan (vii) tingkat kinerja personil. Secara rinci hasil pengukuran kinerja enterprise yang dilakukan oleh sistem data warehouse dan data mining adalah sebagai berikut.

\section{i. KPI 1: Kinerja Presentasi Luas (PL)}

Pengkuran kinerja KPI 1: pencapaian presentasi luas (PL) oleh sistem data warehouse dan data mining ditampilkan dalam bentuk output screen yang memuat jumlah realisasi presentasi luas, target, dan prosentase pencapaian presentasi luas terhadap target.

\section{KINERJA KPI 1 : PRESENTASI LUAS \\ PERGURUAN TINGGI RAHARJA}

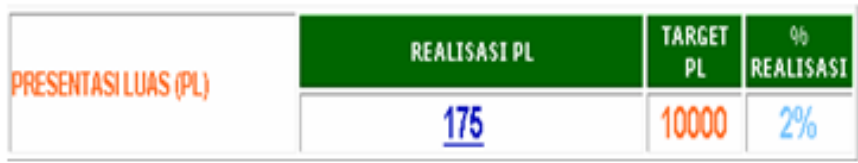

Gambar 2. Hasil pengukuran kinerja presentasi luas 
Pada gambar dua, sistem data warehouse dan data mining menampilkan hasil pengkuran kinerja realisasi presentasi luas dan prosentasenya terhadap target yang ditetapkan. Hasil pengukuran ditampilkan dengan metode data mart query (DMQ) seperti yang juga digunakan oleh Untung Rahardja, et. al [7]. Metode ini dipilih karena dapat langsung menampilkan source code pada display dan proses query yang dikerjakan oleh engine. Berdasarkan hasil pengukuran, manajemen dapat mengevaluasi kinerja enterprise pada aspek presentasi luas. Manajemen juga dapat mengambil keputusan strategis untuk meningkatkan kinerja enterprise dalam mencapai target presentasi luas, dan. user pada level tertentu dapat mengetahui informasi detail tentang realisasi presentasi luas (gambar 2).

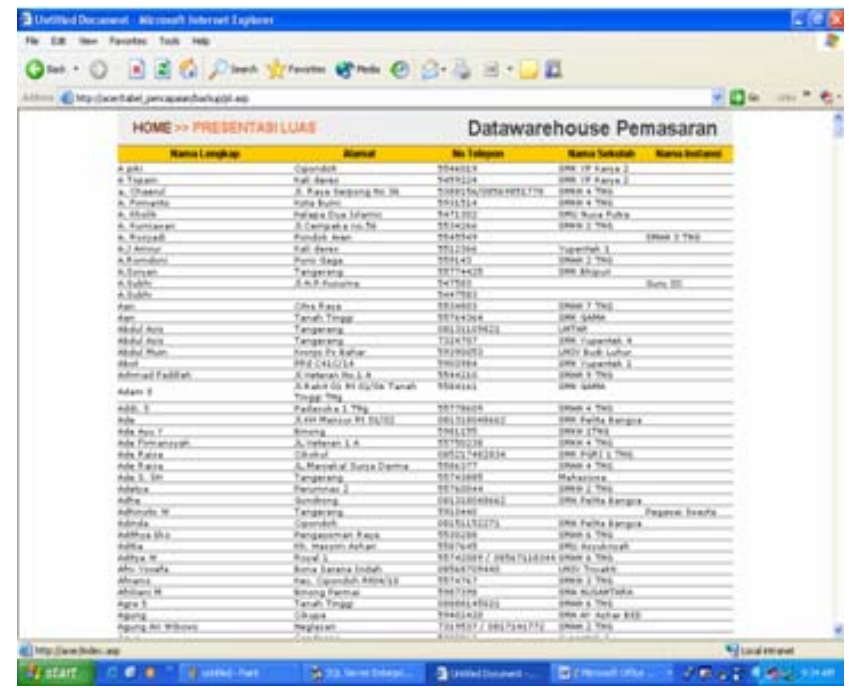

Gambar 2. Detail pencapaian presentasi luas

Gambar dua menampilkan data presentasi luas secara detail hasil dari mining data. Informasi yang ditampilkan sistem dapat dimanfaatkan oleh user sesuai dengan tingkatan dan kebutuhannya.

\section{ii.Pengkuran KPI 2: Kinerja Presentasi Murni (PM)}

Hasil pengukuran terhadap kinerja KPI 2: pencapaian presentasi murni (PM) oleh sistem ditampilkan dalam bentuk screen output yang memuat jumlah capaian realisasi presentasi murni, target PM, prosentase pencapaian PM terhadap target (gambar $3)$. 


\section{KINERJA KPI 2: PRESENTASI MURNI}

PER GURUAN TINGGI RAHARJA

\begin{tabular}{|c|c|c|c|c|}
\hline \multirow[t]{2}{*}{ PRESENTASIMURN (PMA) } & REALSASI PM & $\begin{array}{c}\text { TARGET } \\
\text { PM } \\
\end{array}$ & $\begin{array}{c}\text { CHREALSASI } \\
\text { PM }\end{array}$ & \\
\hline & $\underline{45}$ & 1600 & $3 \%$ & $26 \%$ \\
\hline
\end{tabular}

Gambar 3. Pengukuran kinerja presentasi murni

Hasil pengukuran kinerja KPI presentasi murni pada gambar tiga berfungsi untuk memberikan informasi kepada manajemen puncak dan user tentang kinerja panitia penerimaan mahasiswa baru dari aspek realisasi target presentasi murni, dan rasio (prosentase) pencapaiannya terhadap target yang telah ditetapkan. Dari informasi ini, eksekutif dapat mengambil langkah strategis untuk meningkatkan kinerja enterprise dalam mencapai target presentasi murni. Sementara dengan menerapkan data mining, sistem juga dapat menampilkan informasi detail tentang realisasi presentasi murni (gambar 4).

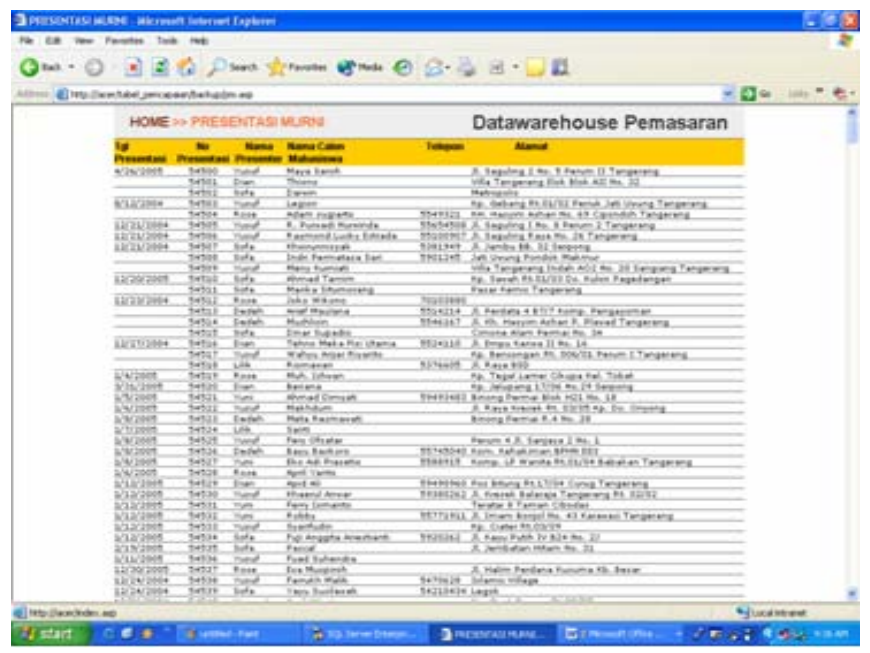

Gambar 4. Detail pencapaian presentasi murni

Tampak pada gambar empat, sistem data warehouse dan data mining menampilkan data presentasi murni secara detail. Informasi detail dapat dimanfaatkan oleh manajemen dan user yang terkait untuk mengetahui tanggal pelaksanaan presentasi murni, nomor presentasi, nama calon mahasiswa, nomor telepon, dan alamat calon mahasiswa. Informasi ini dapat digunakan sesuai dengan kebutuhan tingkatan user, misalnya untuk menghubungi calon mahasiswa baru yang potensial. 


\section{iii.Pengkuran KPI 3: Kinerja Pendaftaran}

Kinerja enterprise pada penelitian ini juga diukur berdasarkan realisasi mahasiswa daftar. Hasil pengkuran kinerja realisasi mahasiswa daftar oleh sistem ditampilkan dalam bentuk screen output seperti pada gambar lima.

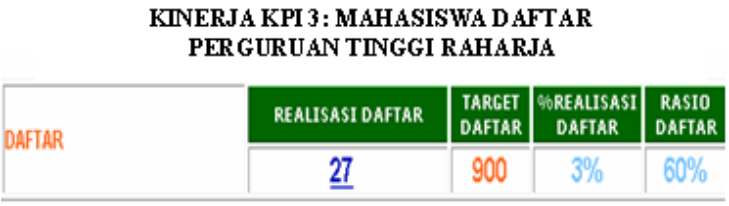

Gambar 5. Pengukuran kinerja mahasiswa daftar

Tampak pada gambar lima, sistem data warehouse dan data mining sebagai tools pengukur kinerja enterprise menampilkan hasil pengukuran kinerja pencapaian mahasiswa daftar dan prosentase realisasi pencapaian target mahasiswa daftar. Dengan dukungan informasi yang ditampilkan sistem, manajemen dapat melakukan evaluasi kinerja divisi pemasaran dari aspek realisasi pencapaian target mahasiswa daftar. Hasil pengukuran ini dapat membantuk manajemen dalam mengambil keputusan strategis untuk meningkatkan kinerja panitia penerimaan mahasiswa baru dari aspek pencapaian target mahasiswa daftar. Selain itu, sistem yang dibangun juga dapat menampilkan informasi detail tentang realisasi mahasiswa daftar (gambar $6)$.

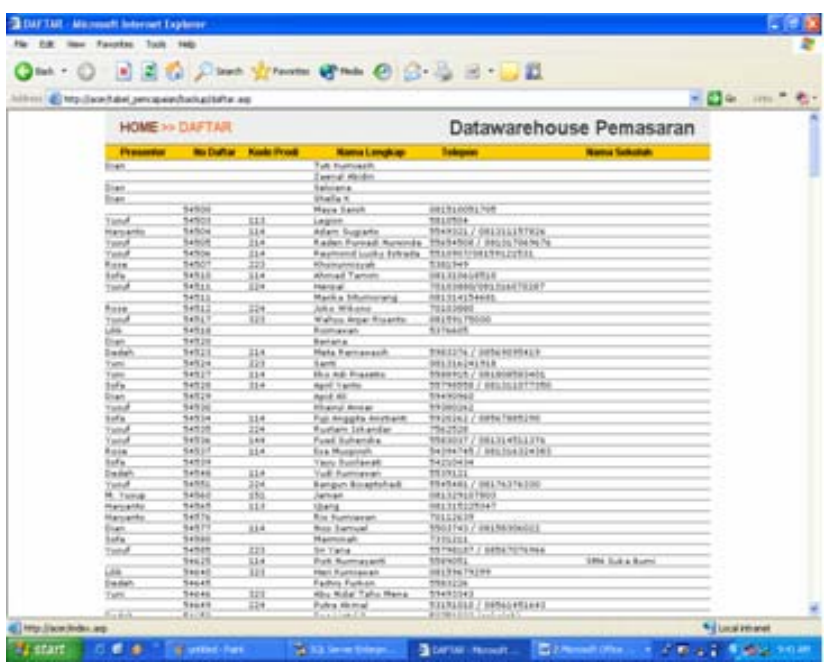

Gambar 6. Detail pencapaian mahasiswa daftar 
Tampak pada gambar enam, sistem yang dibuat menampilkan data realisasi calon mahasiswa baru yang mendaftar. Informasi detail mahasiswa daftar dapat dimanfaatkan untuk mengetahui informasi tentang nama presenter, nomor pendaftaran, nama lengkap calon mahasiswa, nomor telepon, dan asal sekolah calon mahasiswa yang mendaftar.

\section{iv.Pengukuran KPI 4: Kinerja Registrasi}

Implementasi data warehouse dan data mining sebagai tools pengukur kinerja enterprise juga mengukur kinerja realisasi mahasiswa registrasi sebagai KPI 4 sekaligus sebagai value stream kinerja enterprise bagian penerimaan mahasiswa baru. Hasil pengukuran kinerja KPI 4 oleh sistem ditampilkan seperti pada gambar 7.

KINERJA KPI 4: MAHASISWA REGISTRASI

PERGURUAN TINGGI RAHARJA

\begin{tabular}{|c|c|c|c|c|}
\hline \multirow{2}{*}{ REGISTRASI } & REALSASI REG & $\begin{array}{c}\text { TaRGE } \\
\text { REG }\end{array}$ & $\begin{array}{c}\text { GrREALISASI } \\
\text { REG }\end{array}$ & $\begin{array}{c}\text { RASI0 } \\
\text { REG }\end{array}$ \\
\cline { 2 - 6 } & $\underline{14}$ & 700 & $2 \%$ & $52 \%$ \\
\hline
\end{tabular}

Gambar 7. Pengukuran kinerja mahasiswa registrasi

Hasil pengkuran terhadap tigkat kinerja KPI 4: mahasiswa registrasi, ditampilkan jumlah mahasiswa registrasi, dan tingkat kinerja registrasi terhadap target dalam bentuk prosentase (gambar 7). Hasil pengukuran ini mencerminkan tingkat kinerja enterprise Perguruan Tinggi Raharja dalam hal penerimaan mahasiswa baru. Hasil pengkuran kinerja KPI 4 mendukung manajemen dalam membuat keputusan untuk meningkatkan tingkat kinerja pencapaian mahasiswa registrasi. Sistem yang dibangun juga dapat menampilkan data mahasiswa baru yang registrasi secara detail (gambar 8).

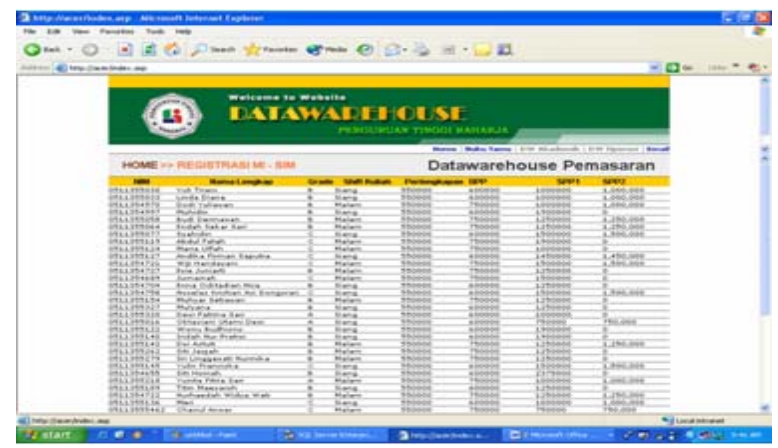

Gambar 8. Detail pencapaian mahasiswa registrasi 
Tampak di gambar delapan, data mahasiswa registrasi ditampilkan secara detail hasil dari data mining yang terdiri terdiri dari: nomor induk mahasiswa, nama, grade ujian saringan masuk, shift kuliah, dan status pelunasan biaya perkuliahan.

\section{v.Pengukuran KPI 5: Kinerja Registrasi Perjurusan dan Perkonsentrasi}

Untuk menjamin keberlanjutan jurusan, setiap tahun ditetapkan target penerimaan mahasiswa baru perjurusan. Karena itu, sistem data warehouse dan data mining sebagai tools pengukur kinerja enterprise yang dibuat pada penelitian ini juga menampilkan tingkat kinerja realisasi mahasiswa baru berdasarkan jurusan dan konsentrasi sebagai KPI 5 (gambar 9). KPI 5 merupakan penerapan prinsip data mining yang sering dianggap sebagai bagian dari knowledge discovery in data base $(K D D)$ yaitu sebuah proses mencari pengetahuan yang bermanfaat dari data yang berjumlah besar [8].

\section{KINERJA KPI 5 : MAHASISWA REGISTRASI PERJURUSAN PER GURUAN TINGGI RAHARJA}

\begin{tabular}{|c|c|c|c|c|c|c|c|c|c|c|c|c|c|}
\hline \multicolumn{14}{|c|}{ TARGET PERUURUSAN PERKONSENTRASI DAN REALISASINYA } \\
\hline $\begin{array}{l}\text { MI- } \\
\text { AMI }\end{array}$ & $\begin{array}{l}\text { M!- } \\
\text { CGA }\end{array}$ & $\begin{array}{l}\text { M!- } \\
\text { SIM }\end{array}$ & $\begin{array}{l}M ! \cdot \\
A G D\end{array}$ & TI-TSA & TI-TKA & $\begin{array}{l}\text { KA. } \\
\text { KAP }\end{array}$ & $\begin{array}{l}\mathrm{KA}- \\
\text { KAK }\end{array}$ & $\begin{array}{l}\text { S!. } \\
\text { SIM }\end{array}$ & $\begin{array}{l}\text { S!· } \\
\text { ECE }\end{array}$ & $\begin{array}{l}\text { SI. } \\
\text { COA }\end{array}$ & $\begin{array}{l}\text { TI. } \\
\text { SEG }\end{array}$ & $\begin{array}{l}\text { TI. } \\
\text { MMD }\end{array}$ & $\begin{array}{l}\text { SK. } \\
\cos \end{array}$ \\
\hline$\underline{24}$ & $\underline{8}$ & $\underline{138}$ & $\underline{28}$ & $\underline{41}$ & $\underline{53}$ & $\underline{19}$ & $\underline{71}$ & $\underline{107}$ & $\underline{13}$ & $\underline{5 \underline{3}}$ & $\underline{74}$ & $\underline{Q B}$ & $\underline{31}$ \\
\hline 29 & 29 & 102 & 35 & 41 & 29 & 29 & 41 & 85 & 52 & 53 & 76 & 59 & 40 \\
\hline $69 \%$ & $27 \%$ & $\begin{array}{c}192 \\
\%\end{array}$ & $93 \%$ & $164 \%$ & $151 \%$ & $76 \%$ & $\begin{array}{c}203 \\
\%\end{array}$ & $\begin{array}{c}149 \\
\%\end{array}$ & $28 \%$ & $\begin{array}{c}118 \\
\%\end{array}$ & $\begin{array}{c}114 \\
8\end{array}$ & $136 \%$ & $89 \%$ \\
\hline
\end{tabular}

Gambar 9. Pengukuran kinerja mahasiswa registrasi perjurusan dan perkonsentrasi

Berdasarkan informasi yang ditampilkan pada gambar sembilan, eksekutifmengetahui tingkat kinerja KPI 5 dan sebaran mahasiswa baru berdasarkan jurusan dan konsentrasi. Informasi pada KPI 5 dapat dikategorikan sebagai dashboard untuk manajemen karena menunjukan tingkat kinerja setiap jurusan dan konsentrasi dalam hal penerimaan mahasiswa secara real time. Hasil pengukuran kinerja KPI 5 juga menyampaikan informasi tentang kekuatan setiap jurusan dalam merekrut mahasiswa baru. Dengan demikian sistem data warehouse dan data mining dapat dijadikan sebagai tools pengukur kinerja enterprise yang fungsinya sama dengan dashboard untuk manajemen. Fungsi dashboard pada sistem ini tidak jauh berbeda dengan fungsi dashboard yang dihasilkan pada penelitian Henry Antonius dan Eka Widjaja [6].

\section{vi.Pengkuruan KPI 6: Kinerja Personil Penerimaan Mahasiswa Baru}


Pengukuran KPI 6 dilakukan untuk mengetahui kinerja personil panitia penerimaan mahasiswa baru dalam merealisasikan target presentasi luas, presentasi murni, daftar, dan mahasiswa registrasi sebagai indikator kinerja enterprise Perguruan Tinggi Raharja sebagai objek dalam implementasi sistem. Karena itu, sistem data warehouse dan data mining sebagai tools pengukur kinerja enterprise yang dihasilkan juga bertujuan untuk mendukung manajemen mengukur dan mengevaluasi kinerja staf seperti pada gambar 10 .

KPI 6: KINERJA PERSONIL PENERIMAAN MAHASISWA BARU PERGURUAN TING GI RAHARJA

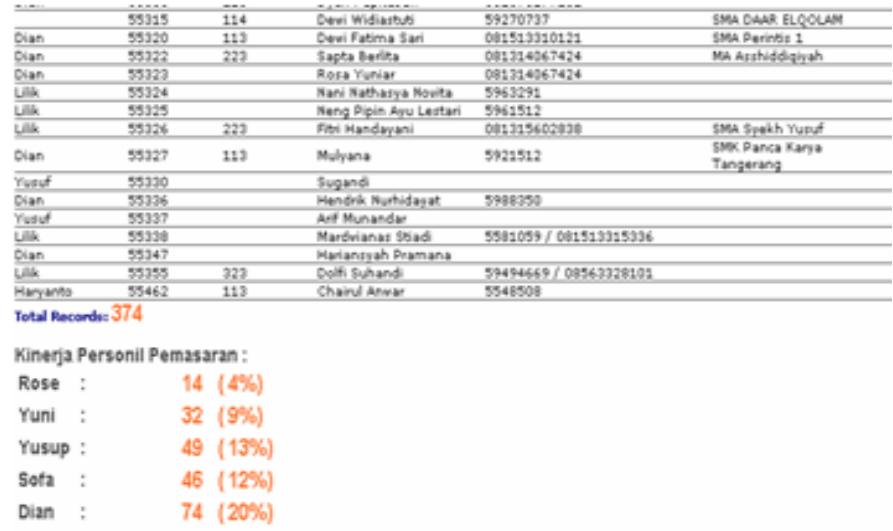

Gambar 10. Hasil pengukuran kinerja personil staf penerimaan mahasiswa baru

Berdasarkan hasil pengukuran oleh sistem seperti pada gambar sepuluh, manajemen enterprise dapat mengetahui kinerja setiap staf penerimaan mahasiswa baru dalam merealisasikan target yang telah ditetapkan. Dari hasil pengukuran tersebut, diketahui staf yang memiliki tingkat kinerja terbaik dan terendah yang ditampilkan dalam bentuk angka dan prosentase.

\section{KESIMPULAN}

Berdasarkan hasil implementasi dan pembahasan, dapat disimpulkan bahwa:

1. Implementasi data warehouse dan data mining sebagai tools pengukur kinerja enterprise memerlukan dukungan sebuah sistem sebagai back office untuk meng-capture data transaksional harian.

2. Sistem data warehouse dan data mining sebagai tools pengukur kinerja enterprise dapat digunakan untuk melakukan pengukuran dan evaluasi 
terhadap kinerja enterprise berdasarkan key performance indicator (KPI) yang telah ditetapkan.

3. Dalam implementasinya, sistem yang dihasilkan pada penelitian ini dapat dijadikan sebagai tools bagi manajemen dalam mengukur dan mengevaluasi tingkat kinerja sesuai dengan bentuk dan kebutuhan enterprise dengan melakukan beberapa penyesuaian.

4. Sistem ini dapat dijadikan tools untuk melaksanakan evaluasi kinerja secara objektifdan mandiri.

5. Model sistem data warehouse dan data mining sebagai tools pengukur kinerja enterprise pada penelitian ini dapat dijadikan sebagai prototipe pengembangan sistem informasi dengan konsep data warehouse, data mining dan business intelligence bagi berbagai organisasi.

\section{REKOMENDASI}

Untuk menghasilkan sebuah sistem data warehouse dan data mining sebagai tools pengukur kinerja enterprise yang lebih efektif, hasil pengkuran kinerja dapat mudah dibaca dan dipahami oleh eksekutif dan user, hendaknya format hasil pengukuran kinerja enterprise oleh sistem ditampilkan dalam sebuah dashboard yang interaktif. Misalnya hasil pengkuran ditampilkan dalam bentuk chart, colour code, atau diagram yang dapat berubah secara real time berdasarkan data yang dicapture oleh sistem back office.

\section{DAFTAR PUSTAKA}

1. Untung Rahardja, (2005), Optimalisasi Decision Support System dengan Konsep Data Warehousing Pada Perguruan Tinggi, Jurnal Cyber Raharja, 3(2), 3541

2. Henderi, (2005), Strategi Membangun Sistem Komputerisasi, Jurnal Cyber Raharja, 3(2), 13-34

3. Yogie Rinaldy Ginitng, Selvia Lorena Br Ginting (2010), Implementasi dan Pengujian Perangkat Lunak CBSTAR sebagai Penerapan Metode Klasifikasi dalam Data Mining, Proseding Seminar Nasional Ilmu Komputer Universitas Diponegoro, 2010, Semarang, 221-229

4. Eka Miranda, Julizar, (2010), Analisis dan Desain Data Warehouse pada Pengembangan Sistem Pengadaan Barang dan Jasa Pemerintah, Proseding 
Seminar Nasional Aplikasi Teknologi Informasi (SNATI) 2010, Yogyakarta, C-1 - C-7

5. Mc. Leod JR., Raymon, (2004), Sistem Informasi Manajemen, Prenhallindo, Jakarta

6. Henry Antonius, Eka Widjaja, (2010), Data Warehouse Pada Rumah Sakit, Proseding Seminar Nasional Aplikasi Teknologi Informasi (SNATI) 2010, Yogyakarta, B-68 - B-72

7. Untung Rahardja, Retantyo Wardoyo, Shakinah Badar,(2010), Data Mart Query (DMQ) Solusi Mempercepat Display Data dalam Distributed Database System, Proseding Seminar Nasional Aplikasi Teknologi Informasi (SNATI) 2010, Yogyakarta, E-17-E-22

8. Sunjana, (2010), Aplikasi Mining Data Mahasiswa dengan Metode Klasifikasi Decision Tree, Proseding Seminar Nasional Aplikasi Teknologi Informasi (SNATI) 2010, Yogyakarta, A-24-A-29 